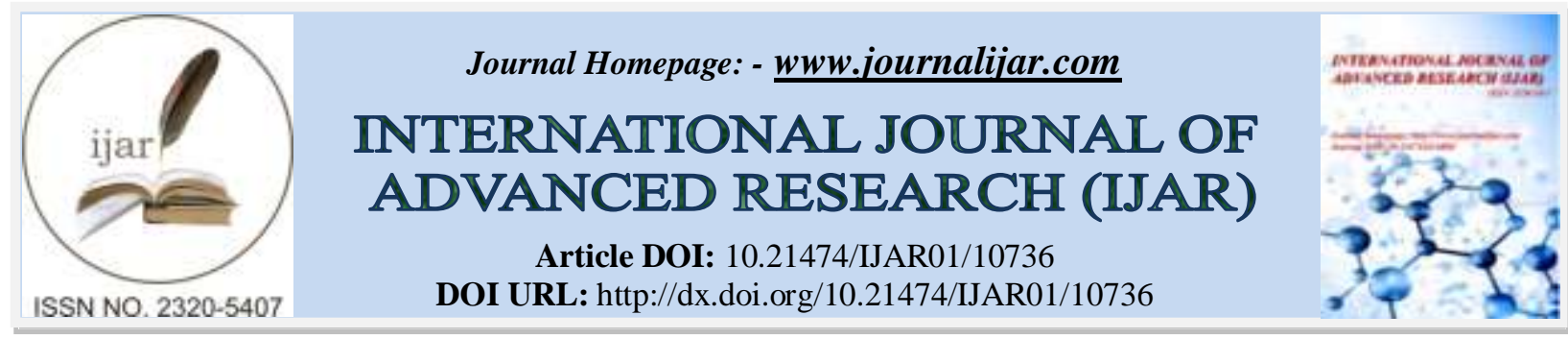

RESEARCH ARTICLE

\title{
CLINICOPATHOLOGICAL CORRELATION OF UPPER GASTROINTESTINAL TRACT ENDOSCOPIC BIOPSIES IN A TERTIARY CARE HOSPITAL IN RURAL AREA OF NORTH INDIA
}

\author{
Dr. Abhimanyu Sharma ${ }^{1}$ and Dr. Kapil Gupta ${ }^{2}$ \\ 1. Lecturer, Department of Pathology, Government Medical College, Jammu, Jammu and Kashmir, India. \\ 2. Registrar, Department of Medicine, Government Medical College, Jammu, Jammu and Kashmir, India.
}

\section{Manuscript Info}

….......................

Manuscript History

Received: 25 January 2020

Final Accepted: 27 February 2020

Published: March 2020

Key words:-

Endoscopic Biopsies, Gastritis,

Scalloping, Polyp

\section{Abstract}

Background: Upper GI endoscopy is a widely used investigation for a variety of upper GI symptoms like dysphagia, dyspepsia, abdominal pain, etc. and when combined with biopsy, its diagnostic accuracy get increased manifold. So the objective of the present study is to diagnose the lesions of upper GIT by studying endoscopic biopsies in relation to age and sex distribution, correlating them with endoscopic diagnoses.

Method: The study included 200 endoscopic biopsies of upper gastrointestinal tract of patients.

Result: There were 26 esophageal, 130 gastric, 44 duodenal biopsies. Non-neoplastic lesions were found to be common $(83.0 \%)$ out of which gastritis was the most common lesion. Most patients presented in the age group of 31-40 years. Majority of the lesions of upper GIT were non-neoplastic. Percentage of concordance between endoscopic \& histologic diagnoses was calculated. In esophageal biopsies, nonneoplastic lesions showed $83.3 \%$ while neoplastic lesions showed $95.0 \%$ concordance. In gastric biopsies, cases of gastritis, ulcer, polyps and carcinoma showed $100 \%, 96.3 \%, 71.4 \%$ and $100 \%$ concordance respectively. In duodenal biopsies, duodenitis, scalloping, polypoidal and carcinomatous lesions showed 100\%, 60.7\%, 0\% and 100\% concordance between the two diagnostic modalities respectively.

Conclusion: The conclusion of the study was that endoscopic examination alone might miss out in diagnosing majority of the lesions. So, histological examination in adjunct with endoscopy should be considered as much more valuable diagnostic tool rather than endoscopy alone.

Copy Right, IJAR, 2020,. All rights reserved.

\section{Introduction:-}

Upper GIT is a frequent site for lesions like GERD, baretts esophagus, celiac disease and particularly malignant tumors. In Indian subcontinent, conferring to National Cancer Registry, esophageal \& gastric cancers are the most frequent cancers in men, while esophageal neoplasm positions third among women ${ }^{1}$. Also, the present decade has seen a rise in the prevalence \& association of $\mathrm{H}$. Pylori with a number of gastrointestinal diseases \& it has recently been described as a gastritis-associated bacterium ${ }^{2,3}$. All of these lesions are detected late in the progression of the ailment, as the patients are either asymptomatic or present with mild, non-specific symptoms. Thus, early detection by endoscopic biopsies, especially of malignancies greatly improves the survival rate ${ }^{1}$. The objective of the study included- To study the spectrum of histopathological lesions both non-neoplastic and neoplastic in patients 
undergoing upper gastrointestinal biopsy. To study age and sex wise distribution of lesions. To correlate histopathological findings with endoscopic findings.

\section{Materials and Method:-}

The present study was a prospective study and 200 patients were included in the study over a period of 2 years. The inclusion criteria consisted of patients with lesions presenting with ulcers, abnormal growths, precancerous conditions and malabsorption syndrome (MAS) and Lesions present in esophagus, stomach and up to second part of duodenum while, patients presenting with lesions in the oral cavity \& oropharynx, inadequate biopsy in terms of no glands, only fibro collagenous tissue and all duodenal biopsies below the second part of duodenum were excluded out.

The endoscopic biopsy specimens so obtained were put in saline, placed on the filter paper with mucosal surface upwards and fixed in 10\% formalin. All the bits were embedded together for ideal visualization. Then, sections 4-6 microns were stained routinely with Haematoxylin and Eosin. The well oriented and adequate endoscopic gastrointestinal biopsies were then correlated with endoscopic findings. The neoplastic lesions were diagnosed as per WHO classification of tumours ${ }^{4}$. The cases of MAS were graded as per modified MARSH criteria ${ }^{5}$.

The data collected was analyzed as percentage of concordance of the two. The discordant cases were analyzed to obtain reasons for discordance. SPSS (Statistical package for social sciences v21.0) was used to perform statistical analyses.

\section{Results:-}

Out of 217 biopsies obtained, 17 were excluded as they contained only fibro collagenous tissue, scanty material \& non-specific findings. Among the neoplastic lesions 34 (17.0\%), the most common was Squamous cell carcinoma constituting 20 cases $(10.0 \%)$ followed by 14 cases of adenocarcinoma $(7.0 \%)$. The most common age group was 51-70 years for both squamous cell \& adenocarcinoma. The non-neoplastic lesions including gastritis, duodenitis, villous atrophy, polyp, lymphangectasia \& GAVE were commonly seen in males accounting for 166 cases (83.0\%). (TABLE 1)

Endoscopic and histological correlation of 26 esophageal biopsies shows that out of 6 cases of esophagitis, 1 was diagnosed as carcinoma upon endoscopy whereas remaining 5 where diagnosed as esophagitis in both yielding $83.3 \%$ concordance. Similarly, out of 20 cases of carcinoma, 19 were found to be malignant on both endoscopy as well as histology whereas 1 case was documented as esophagitis upon endoscopy accounting to $95.0 \%$ concordance. (TABLE 2)

Table 1:- Age \& sex wise distribution of upper gastrointestinal lesions:

\begin{tabular}{|c|c|c|c|c|c|c|c|c|c|c|c|c|c|c|c|c|c|}
\hline \multirow{3}{*}{$\begin{array}{l}\text { Age } \\
\text { in } \\
\text { years }\end{array}$} & \multicolumn{4}{|c|}{ Esophagus } & \multicolumn{6}{|c|}{ Stomach } & \multicolumn{6}{|c|}{ Duodenum } & \multirow[t]{3}{*}{ Total } \\
\hline & \multicolumn{2}{|c|}{ Esophagitis } & \multicolumn{2}{|c|}{$\begin{array}{l}\text { Esophageal } \\
\text { malignancy }\end{array}$} & \multicolumn{2}{|c|}{ Gastritis } & \multicolumn{2}{|c|}{$\begin{array}{l}\text { Gastric } \\
\text { malignancy }\end{array}$} & \multicolumn{2}{|c|}{ Others } & \multicolumn{2}{|c|}{ Duodenitis } & \multicolumn{2}{|c|}{$\begin{array}{l}\text { Duodenal } \\
\text { malignancy }\end{array}$} & \multicolumn{2}{|c|}{ Others } & \\
\hline & $\mathrm{M}$ & $\mathrm{F}$ & $\mathrm{M}$ & $\mathrm{F}$ & $\mathrm{M}$ & $\mathrm{F}$ & $\mathrm{M}$ & $\mathrm{F}$ & $\bar{M}$ & $\mathrm{~F}$ & $\bar{M}$ & $\mathrm{~F}$ & $\mathrm{M}$ & $\mathrm{F}$ & $\mathrm{M}$ & $\mathrm{F}$ & \\
\hline $0-10$ & 0 & 0 & 0 & 0 & 0 & 0 & 0 & 0 & 0 & 0 & 0 & 0 & 0 & 0 & 2 & 0 & 2 \\
\hline $\begin{array}{l}11- \\
20\end{array}$ & 0 & 0 & 0 & 0 & 2 & \begin{tabular}{|l|}
0 \\
\end{tabular} & 0 & 0 & 0 & 0 & 2 & 1 & 0 & 0 & 1 & 2 & 8 \\
\hline $\begin{array}{l}21- \\
30\end{array}$ & 2 & 0 & 0 & 0 & 17 & 4 & 1 & 0 & 0 & 0 & 4 & 1 & 0 & 0 & 3 & 4 & 36 \\
\hline $\begin{array}{l}31- \\
40\end{array}$ & 0 & 1 & 0 & 0 & 28 & 9 & 1 & 0 & 1 & 2 & 2 & 2 & 0 & 0 & 4 & 2 & 52 \\
\hline $\begin{array}{l}41- \\
50\end{array}$ & 0 & 1 & 0 & 5 & 14 & 4 & 1 & 1 & 0 & 0 & 1 & 0 & 0 & 0 & 1 & 2 & 30 \\
\hline $\begin{array}{l}51- \\
60\end{array}$ & 1 & 0 & 5 & 2 & 9 & 99 & 2 & 4 & 0 & 0 & 1 & 0 & 0 & 1 & 0 & 2 & 36 \\
\hline $\begin{array}{l}61- \\
70\end{array}$ & 1 & 0 & 4 & 3 & 7 & 2 & 0 & 1 & 1 & 2 & 1 & 0 & 1 & 0 & 2 & 0 & 25 \\
\hline 71- & 0 & 0 & 1 & 0 & 6 & 1 & 1 & 0 & 0 & 0 & 0 & 0 & 0 & 0 & 1 & 1 & 11 \\
\hline
\end{tabular}




\begin{tabular}{|l|l|l|l|l|l|l|l|l|l|l|l|l|l|l|l|l|l|}
\hline 80 & & & & & & & & & & & & & & & & & \\
\hline Total & 4 & 2 & 10 & 10 & 83 & 29 & 6 & 6 & 2 & 4 & 11 & 4 & 1 & 1 & 14 & 13 & 200 \\
\hline
\end{tabular}

Table 2:- Correlation of endoscopic and histological diagnoses in esophageal biopsies.

\begin{tabular}{|l|l|l|l|l|}
\hline \multirow{2}{*}{ Endoscopy } & \multicolumn{3}{|l|}{ Histology } & \multirow{2}{l|}{$\begin{array}{l}\text { Percentage } \\
\text { concordance (\%) }\end{array}$} \\
\cline { 2 - 5 } & Esophagitis & $\begin{array}{l}\text { Squamous cell } \\
\text { carcinoma }\end{array}$ & Total & \\
\hline Esophagitis & 5 & 1 & 6 & 83.3 \\
\hline Carcinoma & 1 & 19 & 20 & 95.0 \\
\hline Total (26) & 6 & 20 & 26 & - \\
\hline
\end{tabular}

Table 3:- Correlation of endoscopic and histological diagnoses in gastric biopsies.

\begin{tabular}{|l|l|l|l|l|l|l|l|}
\hline Endoscopy & \multicolumn{9}{|l|}{ Histology } & Save & $\begin{array}{l}\text { Adeno } \\
\text { carcinoma }\end{array}$ \\
\hline & Gastritis & Polyp & Gavet ring & $\begin{array}{l}\text { Total } \\
\text { cell } \\
\text { carcinoma }\end{array}$ & $\begin{array}{l}\text { Percentage of } \\
\text { concordance } \\
(\%)\end{array}$ \\
\hline Gastritis & 86 & 0 & 0 & 0 & 0 & 86 & 100 \\
\hline Ulcer & 26 & 0 & 0 & 0 & 1 & 27 & 96.3 \\
\hline Polypoidal lesion & 0 & 5 & 1 & 1 & 0 & 7 & 71.4 \\
\hline Carcinoma & 0 & 0 & 0 & 7 & 3 & 10 & 100 \\
\hline Total (130) & 112 & 5 & 1 & 8 & 4 & 130 & - \\
\hline
\end{tabular}

Table 4:- Correlation of endoscopic and histological diagnoses in duodenal biopsies.

\begin{tabular}{|c|c|c|c|c|c|c|c|}
\hline & Histology & & & & & & \\
\hline endoscopy & Duodenitis & $\begin{array}{l}\text { Intra epithelial } \\
\text { lymphocytosis }\end{array}$ & $\begin{array}{l}\text { Villous } \\
\text { atrophy }\end{array}$ & Lymphangectasia & Adenocarcinoma & Total & $\begin{array}{l}\text { Percentage } \\
\text { of } \\
\text { concordance } \\
(\%)\end{array}$ \\
\hline Duodenitis & 13 & 0 & 0 & 0 & 0 & 13 & 100 \\
\hline $\begin{array}{l}\text { Scalloping } \\
\text { with loss } \\
\text { of folds }\end{array}$ & 2 & 8 & 17 & 1 & 0 & 28 & 60.7 \\
\hline $\begin{array}{l}\text { Polypoidal } \\
\text { lesion }\end{array}$ & 0 & 0 & 0 & 1 & 0 & 1 & 0 \\
\hline Carcinoma & 0 & 0 & 0 & 0 & 2 & 2 & 100 \\
\hline Total (44) & 15 & 8 & 17 & 2 & 2 & 44 & - \\
\hline
\end{tabular}

Endoscopic and histological correlation of 44 duodenal biopsies shows that the most common discordant lesion on endoscopy was polypoidal lesion wherein a case of lymphangectasia was diagnosed to be a polypoidal lesion upon endoscopy, followed by scalloping lesions which accounted for $60.7 \%$ concordance between the two diagnostic methods. Duodenitis and carcinomas yielded $100 \%$ concordance in our study. (TABLE 4) 


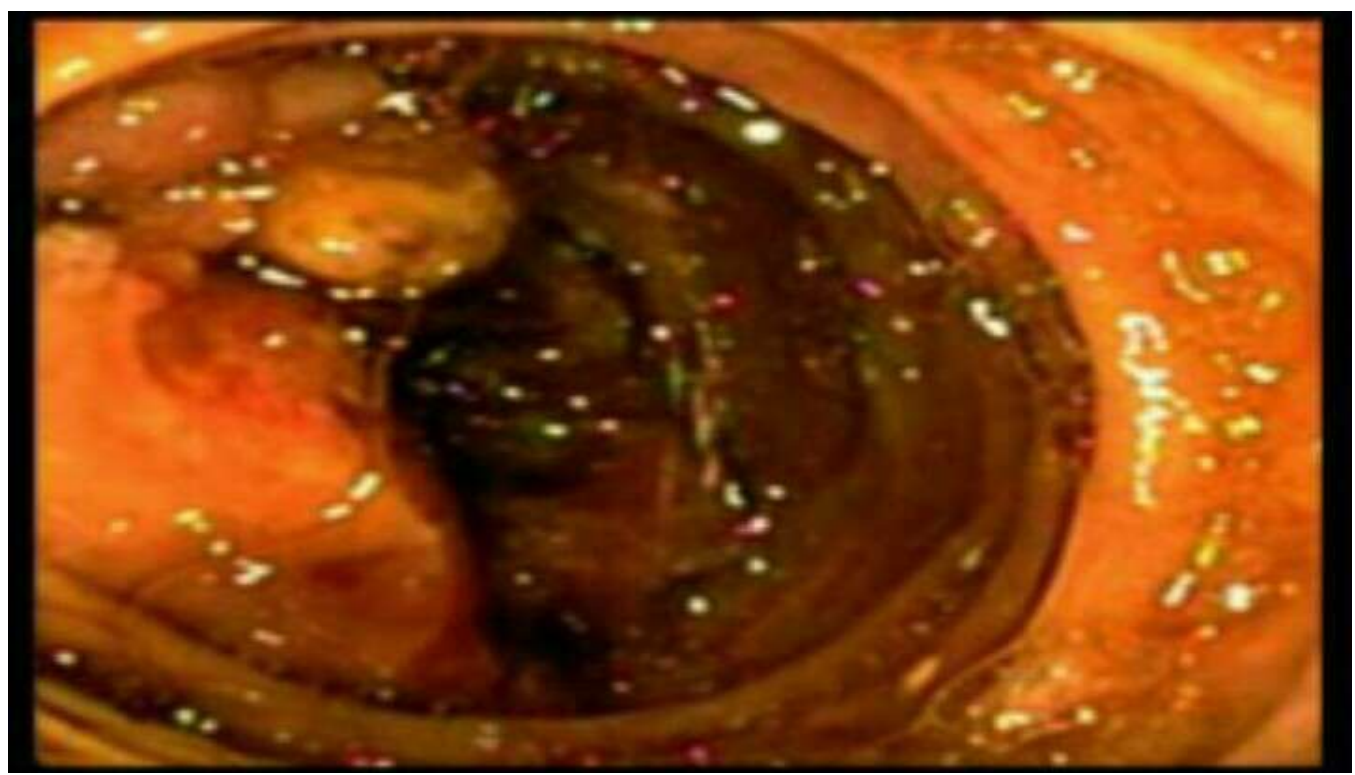

Figure 1:- Endoscopic view of proliferating lesion in duodenum.

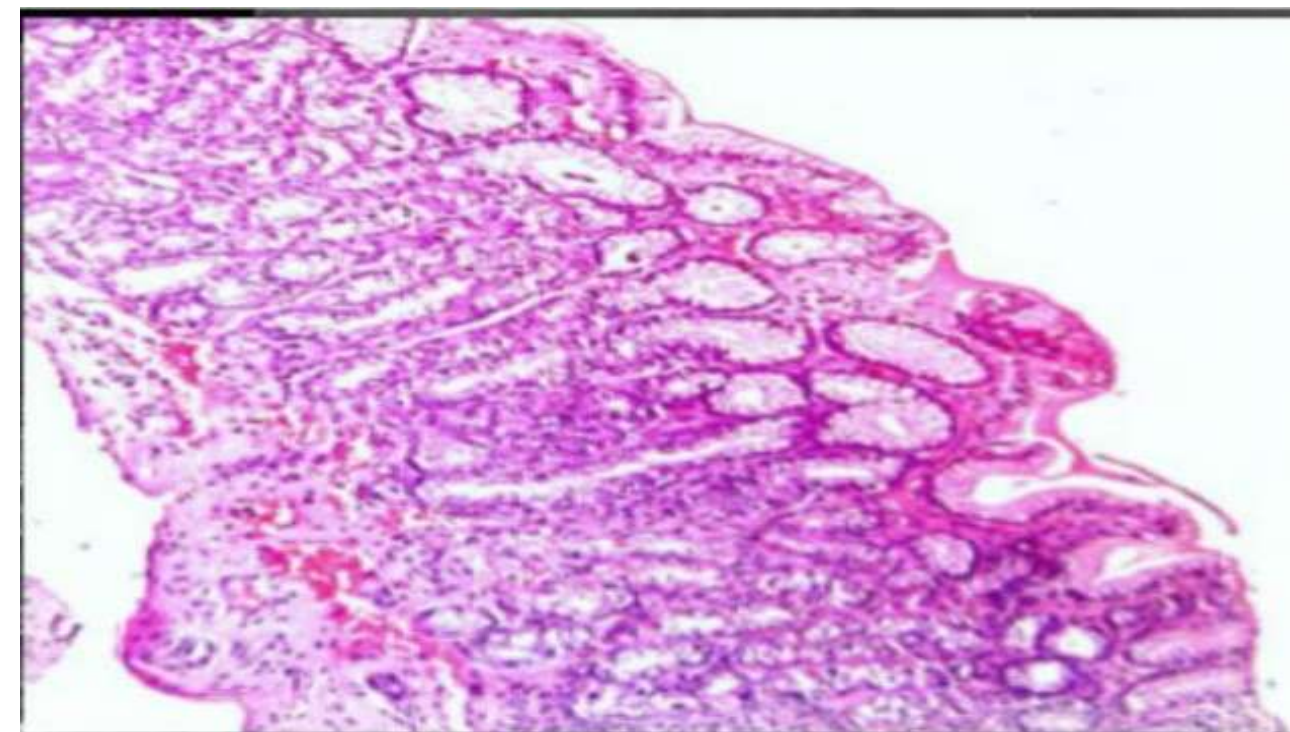

Figure 2:- Low power view of antral biopsy with GAVE, revealing increased number of blood vessels in the lamina propria (H \& E; X100).

\section{Discussion:-}

Endoscopy, when combined with biopsy is an easy, minimally invasive \& cost effective procedure when it comes to arriving at a specific diagnosis of a patient with non-specific symptoms. The present study included such endoscopic biopsies that were studied with respect to age \& sex distribution and correlation with endoscopic findings. Out of total 217 endoscopic biopsies from upper GIT , 200 lesions were included in the study. The biopsies that were included in the study comprised of $26(13.0 \%)$ esophageal biopsies \& $130(65 \%)$ gastric biopsies. The remaining were $44(22 \%)$ duodenal biopsies \& none $(0.0 \%)$ from GEJ. These lesions were then classified non-neoplastic lesions which, comprised $166(83.0 \%)$ cases \& neoplastic lesions, which comprised 34 (17\%) cases. The age \& sex distribution, correlation with endoscopic findings were calculated separately for both these categories.

In the present study it was found that the majority of patients were between 31-40 years of age in contrast to study done by Froehlich et $\mathrm{al}^{6}$, where the age group was found to be over 60 years. The non-neoplastic lesions included cases of esophagitis, gastritis, GAVE, polyps, duodenitis, villous atrophy\& lymphangectasia. The peak age group of 
non-neoplastic lesions was found to be 31-40 years. These findings were in contrast to the study done by Wei et al where mean age group was 56 years $^{7}$. Gastritis was found to be common in 31-40 years age group in the present study similarly, it was found to be common in 31-40 years in other studies \& the incidence was also found to increase with age ${ }^{8,9}$. In the present study, gastric polyps were found more in females over 31-40 years, \& $61-70$ years age groups. A study done by Ljubicic et al revealed higher incidence of benign gastric polyps in 52-53 years, whereas Cao et al study revealed an equal distribution pattern in young \& elderly adults ${ }^{10,11}$. The neoplastic lesions were most commonly seen in 51-60 years age group, similar to a study done by Vidyavathi et al \& Bazaz et al where the peak age group of upper GI neoplasms was found to be 51-60 years \& 31-60 years respectively ${ }^{1,12}$. A study done by Hammadi et al showed a peak age incidence of $45-54$ years ${ }^{13}$. Esophagus: Esophageal squamous cell carcinomas formed the most common neoplastic lesion with peak age distribution in 51-70 year age group, similar to Pedram et al where the peak age was found to be 61.8 years ${ }^{14}$. Stomach: Gastric adenocarcinomas including signet ring types were more common in 51-60 years age group, while Ozoran et al found a higher incidence in 3rd \& 4th decades ${ }^{15}$. Duodenum: Duodenal adenocarcinomas were seen in 51-70 years age group in the present study. Ryder et al revealed a mean age incidence of 61.3 years for duodenal adenocarcinomas ${ }^{16}$.

In the present study the number of males undergoing upper GI endoscopy were more than the number of females. Similar findings were found in the previous study by David ${ }^{17}$, Froehlich et $\mathrm{al}^{6}$ and Shennak et al ${ }^{18}$. In all the three studies the men out numbered women due to more prevalence of smoking, alcoholism and stressful life. The nonneoplastic lesions were also commonly seen in males $(69.3 \%)$, which was similar to Lee et al ${ }^{19}$. Gastritis was also more common in males in the present study similar to Afzal et al but in contrast to Adisa et al where it was more common in females ${ }^{20}$. This could be due to more number of males attending the hospital and also due to higher consumption of alcohol in males. In the present study, gastric polyps were found to occur more in frequency in females than males while Ljubicic et al showed a slight male preponderance ${ }^{10}$. Overall, the neoplastic lesions were similar in males $(50.0 \%)$ and females $(50.0 \%)$ in contrast to Vidyavathi et al, where it showed male predominance $(64 \%)$ and to Hammadi et al where females showed higher frequency $(52 \%)^{1,13}$. Esophagus: The esophageal carcinomas showed equal preponderance $(50.0 \%)$ each with a male-female ratio of $1: 1$, while Pedram et al showed a female preponderance with a male-female ratio of $0.84: 1^{14}$. Stomach: Gastric carcinomas were again equal in both sexes with a male-female ratio of 1:1 in the present study, similar to Ozoran et al, who too did not find any sex predilection $^{15}$. Duodenum: The frequency of duodenal carcinomas were also similar in both sexes, in contrast to that of Ryder et al, who figured male predominance ${ }^{16}$.

The esophageal lesions showed a better correlation between the two diagnostic modalities with positive endoscopy findings. Out of 20 esophageal carcinomas, 19 diagnosed as carcinomas on endoscopy were confirmed by histology whereas 1 case came out benign. Esophagitis seen as inflammatory change could only be found in 5 out of 6 histologically confirmed cases while 1 was diagnosed as carcinoma endoscopically. According to Pope ${ }^{21}$ endoscopic $^{2}$ finding did not rule out possibility of esophagitis, confirming our study that few lesions are likely to be missed on endoscopic examination alone.

In the gastric lesions there was a modest concordance between the two diagnostic modalities specially in cases of diagnosing polypoidal lesions wherein out of 5 histologically confirmed cases of polyps, a case of GAVE and another of carcinoma was misjudged to be a polyp on endoscopy accounting for $71.4 \%$ concordance. Thus because of this discordance the endoscopist should convey the findings as erythema, exudate to the pathologist along with the biopsy rather than diagnosing it alone. Morson ${ }^{22}$ has also documented similar observations. The carcinomas on the other hand yielded $100 \%$ concordance in our study.

In the duodenal lesions too, the correlation studies showed similar trends as in gastric lesions with polypoidal lesions yielding total discordance, as single case diagnosed as polyp on endoscopy came out as lymphangectasia upon histology. This was followed by scalloping lesions with loss of folds seen in 28 cases on endoscopy with only 17 confirmed cases on histology accounting for $60.7 \%$ concordance between the two methods. Our findings were in agreement to the study by Paoluzi et $\mathrm{al}^{23}$. Similar to the gastric findings, the carcinomas yielded $100 \%$ concordance in our study.

\section{Conclusion:-}

The conclusion of the study was that endoscopic examination alone might miss out in diagnosing majority of the lesions. So, histological examination in adjunct with endoscopy should be considered as much more valuable diagnostic tool rather than endoscopy alone. 


\section{Bibliography:-}

1. Vidyavathi K, Harendrakumar ML, Lakshmana Kumar YC. Correlation of endoscopic brush cytology with biopsy in diagnosis of upper gastrointestinal neoplasms. Indian J Pathol Microbiol. 2008;51(4):489-92.

2. Cheong YM, Ng YP, Ong SC, Chang PT, Pillai SS. Detection of Helicobacter pylori from endoscopic biopsies and the biochemical characteristics of these isolates. Malays J Pathol. 1990;12(2):97-100.

3. Ahluwalia C, Jain M, Mehta G, Kumar N. Comparison of endoscopic brush cytology with biopsy for detection of Helicobacter pylori in patients with gastroduodenal diseases. Indian J Pathol Microbiol. 2001;44(3):283-88.

4. Aaltonen LA, Hamilton SR, editors. World Health Organization classification of tumours. Pathology and genetics of tumours of the digestive system. Lyon: IARC Press; 2000.pp.314.

5. Shariff S. Gastrointestinal System. In: Fundamentals of Surgical Pathology. New Delhi: Jaypee Brothers Publishers; 2010. pp.135-88.

6. Froehlich F, Pache I, Burnand B, Vader J, Fried M, Kosecoff J, et al. Underutilization of upper gastrointestinal endoscopy. Gastroenterology. 1997;112(3):690-97.

7. Wei W-Q, Abnet CC, Lu N, Roth MJ, Wang G-Q, Dye BA, et al. Risk factors for oesophageal squamous dysplasia in adult inhabitants of a high risk region of China. Gut. 2005;54(6):759-63.

8. Al-Ammar NS, Hammadi SS, Al-Saimary I. Demographical study of H. pylori associated gastritis. Adv Bioresearch. 2011;2(1):47-61.

9. Muszyński J, Biernacka D, Siemińska J, Górnicka B, Bogdańska M. [Effect of age and sex on the occurrence of gastritis changes in gastric mucosa]. Pol Arch Med Wewnętrznej. 1996;95(6):542-48.

10. Ljubicić N, Kujundzić M, Roić G, Banić M, Cupić H, Doko M, et al. Benign epithelial gastric polyps-frequency, location, and age and sex distribution. Coll Antropol. 2002;26(1):55-60.

11. Cao H, Wang B, Zhang Z, Zhang H, Qu R. Distribution trends of gastric polyps: an endoscopy database analysis of 24121 northern Chinese patients. J Gastroenterol Hepatol. 2012;27(7):1175-80.

12. Bazaz-Malik G, Lal N. Malignant tumours of the digestive tract. A twenty five year study. Indian J Pathol Microbiol. 1989;32(3):179-85.

13. Hammadi SS, Jasim AH. Endoscopic biopsy and brushing cytology compared to open tissue biopsy: A study of 50 patients with upper gastrointestinal tract malignancies. Med J Basrah Univ. 2009;27(2):80-3.

14. Pedram A, Mahmodlou R, Enshayi A, Sepehrvand N. Esophageal cancer in northwestern Iran. Indian J Cancer. 2011;48(2):165-69.

15. Özoran Y, Albayrak L, Turgutalp H, Bakir T. Atrophic gastritis, intestinal metaplasia, Gastric carcinoma and it's variants in dyspeptic cases of eastern Black Sea region. J Islam Acad Sci. 1992;5(2):118-22.

16. Ryder NM, Ko CY, Hines OJ, Gloor B, Reber HA. Primary duodenal adenocarcinoma: a 40-year experience. Arch Surg. 2000;135(9):1070-75.

17. Lieberman DA, De Garmo PL, Fleischer DE, Eisen GM, Helfand M. Patterns of endoscopy use in the United States. Gastroenterology. 2000;118(3):619-24.

18. Shennak MM, Tarawneh MS, Al-Sheikh TM. Upper gastrointestinal diseases in symptomatic Jordanians: A prospective endoscopic study. Ann Saudi Med. 1997;17(4):471-74.

19. Lee SB, Kang HY, Kim KI, Ahn DH. The Diagnostic Accuracy of Endoscopic Biopsy for Gastric Dysplasia. J Gastric Cancer. 2010;10(4):175-81.

20. Adisa JO, Musa AB, Yima UI, Egbujo EC. Helicobacter Pylori Associated Gastritis in North-Eastern Nigeria: A Histopathologic Study. E-Int Sci Res J. 2011;3(1):1-4.

21. Pope CE. Gastroesophageal reflux disease (reflux esophagitis). In: Sleisenger MH, Fordtran JS, editors. Gastrointestinal disease: pathophysiology, diagnosis, management. 3rd ed. Philadelphia: Saunders; 1983. pp.449.

22. Morson BC, Dawson IMP. Gastrointestinal Pathology. 2nd ed. Oxford: Blackwell Scientific; 1979. pp.610.

23. Paoluzi P, Pallone F, Palazzesi P, Marcheggiano A, Iannoni C. Frequency and extent of bulbar duodenitis in duodenal ulcer, endoscopic and histological study. Endoscopy. 1982;14(6):193-95. 